\title{
Resolution of 2,3-dihydro-benzofuran-3-ols
}

\author{
CÉDRIC CHARRIER and PHILIPPE BERTRAND* \\ Synthèse et Réactivité des Substances Naturelles, CNRS UMR 6514, Université de Poitiers, \\ 40 Avenue du Recteur Pineau, Poitiers, 86022, France \\ e-mail: philippe.bertrand@univ-poitiers.fr
}

MS received 23 July 2010; revised 22 April 2011; accepted 19 May 2011

\begin{abstract}
A new method for the preparation of enantiopure 2,2-disubstituted 2,3-dihydro-benzofuran-3-ols is described. A short synthesis is designed for obtaining various 2,2-disubstitued benzofuran-3-ols as racemic mixtures of the two possible syn and anti diastereoisomers, which can be separated after silylation. The major racemic anti isomers were transesterified using (R)-pentolactone, allowing separation of the pure enantiomers.
\end{abstract}

Keywords. benzofuran-3-ol; resolution; pentolactone.

\section{Introduction}

Dibenzofuranone is a moiety, found in many biologically significant natural products, ${ }^{1}$ such as the rocaglamide 1 insecticide or the synthetic PPAR $\alpha$ agonist $2,{ }^{2}$ the receptor $\alpha-2$ antagonist Efaroxan $\mathbf{3}^{3}$ and the vasinfectins $\mathbf{4}^{4}$ (figure 1). These compounds may be mono- or disubstituted in position 2, generating a stereogenic centre requiring asymmetric synthesis. Although many methods have been described for enantioselective preparation of 2,3-dihydro-benzofuran, ${ }^{2,4-7}$ direct preparation of enantiopure 2,3-dihydrobenzofuran-3ols is still a challenging, especially when a 2,2 disubstituted derivative is needed. Involved in the preparation of biologically active molecules 5 based on benzofuran3 -ones, ${ }^{8}$ we studied a possible practical preparation of the two enantiomers of 2,2-disubstitued benzofuran-3ols 6 to obtain enantiopure compounds 5 (figure 1). We focused more specifically on a methodology designed to prepare structures $\mathbf{6}$ where the $\mathrm{R}$ group could be modulated, and also allowing further modifications at any synthetic stage. The $\mathrm{R}^{\prime}$ group should preferably be a carbonyl function used to prepare the butadiene chain found in compound 5. Clive described the use of the Enders ${ }^{9}$ method with the SAMP hydrazine for the conversion of indanones to the corresponding SAMP hydrazone. Despite the possible access to the other enantiomer with the RAMP hydrazine, this work showed that methylation followed by carbonylation gave a poor final diastereoisomeric excess. ${ }^{10}$ Some recycling methods ${ }^{11}$ found in the literature can

*For correspondence mitigate the inadequateness of such costly methods. Recently, a synthesis of 2,2-disubstituted indan-3-ols and benzofuran-3-ols was described utilizing HPLCbased separation for the indanols, while a Jacobsen's asymmetric synthesis was used for the preparation of the benzofuranols due to impossible HPLC separation of the stereoisomers. ${ }^{12}$ In the case of 2,3dihydrobenzofurane, a resolution-based method was described, ${ }^{13}$ prompting us to develop an equivalent method for the resolution of 2,3-dihydrobenzofuran3 -ols that should give both enantiomers in a standard sequence. Our strategy is focused on the access to alcohols $\mathbf{6}$ from diversely substituted salicylaldehydes, with subsequent transformations to obtain a possible resolution.

\section{Experimental}

Abbreviations used: PE: petroleum ether, EtOAc: ethyl acetate, THF: tetrahydrofuran, EDC: 1[3(dimethylamino)propyl]-3-ethyl-carbodiimide hydrochloride, DMAP: dimethylaminopyridine.

\subsection{4-Dimethylamino-2-hydroxy-benzaldehyde $\mathbf{8 a}$}

Phosphorus oxychloride $(63.7 \mathrm{~g}, 38.7 \mathrm{ml})$ was added drop-wise to ice cold DMF (93 ml). After $30 \mathrm{~min}$. of stirring at ambient temperature, N,N-dimethylaminophenol (50 g, $0.336 \mathrm{~mol})$ in DMF (minimum) was added, and the resulting solution heated on a water bath for $1 \mathrm{~h}$. After cooling, the solution was hydrolysed with $\mathrm{NaOH} 1 \mathrm{~N}$ and stirred overnight. The final solution was 
<smiles>CCC1(C2=NCCN2)Cc2ccccc2O1</smiles><smiles>CC[C@]1(C(=O)O)Cc2cc(OCCCOc3ccc(OC(F)(F)F)cc3Cl)ccc2O1</smiles><smiles>[R]c1ccc2c(c1)OC(C)(/C=C(S)/C=C/C(=O)NO)C2=O</smiles>

Figure 1. Benzofuran-based bioactive compounds.

extracted with ether to give 7a as a brown solid (65\%), which was further used without purification. ${ }^{1} \mathrm{H}$ NMR $\left(300 \mathrm{MHz}, \mathrm{CDCl}_{3}\right) \delta \mathrm{ppm}: 11.6(\mathrm{~s}, 1 \mathrm{H}), 9.5(\mathrm{~s}, 1 \mathrm{H})$, $7.29(\mathrm{~d}, 1 \mathrm{H}, J=8.7 \mathrm{~Hz}), 6.32(\mathrm{dd}, 1 \mathrm{H}, J=8.7$, $2.5 \mathrm{~Hz}), 6.08(\mathrm{~d}, 1 \mathrm{H}, J=2.5 \mathrm{~Hz}), 3.0(\mathrm{~s}, 6 \mathrm{H}) ;{ }^{13} \mathrm{C} \mathrm{NMR}$ $\left(75 \mathrm{MHz}, \mathrm{CDCl}_{3}\right) \delta$ ppm: 192.3, 163.9, 156.1, 135.1, 111.6, 104.6, 97.0, 39.9.

\subsection{4-Chloro-2-hydroxy-benzaldehyde 7b}

To a solution of 3-chlorophenol $\mathbf{8 b}(2.57 \mathrm{~g}, 20 \mathrm{mmol})$ in $\mathrm{CH}_{3} \mathrm{CN}(100 \mathrm{ml})$ were added: $\mathrm{MgCl}_{2}(30 \mathrm{mmol})$, $\mathrm{NEt}_{3}(75 \mathrm{mmol})$ and paraformaldehyde $(135 \mathrm{mmol})$. The mixture was refluxed for $3 \mathrm{~h}$ and after cooling to room temperature, $\mathrm{HCl} 6 \mathrm{~N}(50 \mathrm{ml})$ was added. The resulting mixture was extracted with $\mathrm{Et}_{2} \mathrm{O}(3 \times 100 \mathrm{ml})$ dried over $\mathrm{MgSO}_{4}$ and concentrated. Purification (flash chromatography on silica, PE:EtOAc 97:3) gave the phenol $7 \mathbf{b}$ as a solid $(1.88 \mathrm{~g}, 60 \%)$ along with regioisomer $9(0.38 \mathrm{~g}, 12 \%) .{ }^{1} \mathrm{H}$ NMR $\left(300 \mathrm{MHz}, \mathrm{CDCl}_{3}\right) \quad \delta$ ppm: $11.2(\mathrm{~s}, 1 \mathrm{H}), 9.9(\mathrm{~s}, 1 \mathrm{H}), 7.5(\mathrm{~d}, 1 \mathrm{H}, J=7.8 \mathrm{~Hz})$, $7.0(\mathrm{~m}, 1 \mathrm{H})$.

\subsection{6-Dimethylamino-3-hydroxy-2-methyl-2,3-} dihydro-benzofuran-2-carboxylic acid methyl ester $\mathbf{6 a}$

To a solution of phenol 7a (5 g, $0.019 \mathrm{~mol})$ in DMF $(100 \mathrm{ml})$ were added: $\mathrm{K}_{2} \mathrm{CO}_{3}(5.4 \mathrm{~g}, 0.038 \mathrm{~mol})$ and 2bromopropionate methyl ester $(2.2 \mathrm{ml}, 0.019 \mathrm{~mol})$. The solution was heated at $125^{\circ} \mathrm{C}$ for $3 \mathrm{~h}$. After cooling, water was added $(100 \mathrm{ml})$ and the mixture was extracted with $\mathrm{Et}_{2} \mathrm{O}(5 \times 100 \mathrm{ml})$. The combined organic layers were washed with water $(100 \mathrm{ml})$, dried over $\mathrm{MgSO}_{4}$, and concentrated. Purification (flash chromatography, silica, PE:EtOAc 80:20) gave $2.25 \mathrm{~g}$ of $\mathbf{6 a}$ as the single anti isomer $(47 \%) .{ }^{1} \mathrm{H}$ NMR $\left(300 \mathrm{MHz}, \mathrm{CDCl}_{3}\right) \delta \mathrm{ppm}$ : $7.17(\mathrm{~d}, 1 \mathrm{H}, J=8.2 \mathrm{~Hz}), 6.3(\mathrm{~m}, 2 \mathrm{H}), 6.1(\mathrm{~m}, 1 \mathrm{H}), 5.17$ (d, 1H), $3.70(\mathrm{~s}, 3 \mathrm{H}), 2.90(\mathrm{~s}, 6 \mathrm{H}), 2.43(\mathrm{~s}, 1 \mathrm{H}), 1.65(\mathrm{~s}$, $3 \mathrm{H}$ ); ${ }^{13} \mathrm{C}$ NMR $\left(75 \mathrm{MHz}, \mathrm{CDCl}_{3}\right.$ ) $\delta$ ppm: 173.7, 160.8, 153.4, 126.0, 114.8, 106.2, 94.0, 91.4, 76.0, 52.8, 40.5, 18.0.

2.4 6-Chloro-3-hydroxy-2-methyl-2,3-dihydrobenzofuran-2-carboxylic acid methyl ester $\mathbf{6 b}$ (anti + syn diastereoisomers)

${ }^{1} \mathrm{H}$ NMR $\left(300 \mathrm{MHz}, \mathrm{CDCl}_{3}\right) \delta$ ppm: $7.23(\mathrm{~d}, 1 \mathrm{H}, J=$ $8.2 \mathrm{~Hz}), 6.85(\mathrm{~m}, 2 \mathrm{H}), 6.1(\mathrm{~m}, 1 \mathrm{H}), 5.25(\mathrm{~s}, 0.8 \mathrm{H}), 4.90$ $(\mathrm{s}, 0.2 \mathrm{H}), 3.72(\mathrm{~s}, 0.6 \mathrm{H}), 3.70(\mathrm{~s}, 2.4 \mathrm{H}), 2.43(\mathrm{~s}, 0.8 \mathrm{H})$, $1.66(\mathrm{~s}, 0.6 \mathrm{H}), 1.64(\mathrm{~s}, 2.4 \mathrm{H}) ;{ }^{13} \mathrm{C}$ NMR $(75 \mathrm{MHz}$, $\left.\mathrm{CDCl}_{3}\right) \delta$ ppm: 171.3, 170.3, 159.6, 159.5, 136.2, 135.9, 126.7, 126.6, 126.2, 125.1, 121.7, 121.6, 111.4, 111.0, 92.6, 91.6, 78.5, 75.0, 52.7, 52.4, 17.3, 17.0.

2.5 5-Bromo-3-hydroxy-2-methyl-2,3-dihydrobenzofuran-2-carboxylic methyl ester $\mathbf{6 c}$

${ }^{1} \mathrm{H}$ NMR (300 MHz, $\left.\mathrm{CDCl}_{3}\right) \delta$ ppm: $7.50(\mathrm{~d}, 1 \mathrm{H}, J=$ $2.2 \mathrm{~Hz}), 7.38(\mathrm{dd}, 1 \mathrm{H}, J=8.6,2.2 \mathrm{~Hz}), 6.81(\mathrm{~d}, 1 \mathrm{H}$, $J=8.6 \mathrm{~Hz}), 5.35(\mathrm{~d}, 0.9 \mathrm{H}), 4.90(\mathrm{~d}, 0.1 \mathrm{H}), 3.85(\mathrm{~s}$, $0.3 \mathrm{H}), 3.75(\mathrm{~s}, 2.7 \mathrm{H}), 2.0(\mathrm{~s}, 0.9 \mathrm{H}), 1.66(\mathrm{~s}, 0.3 \mathrm{H})$, $1.64(\mathrm{~s}, 2.7 \mathrm{H}) ;{ }^{13} \mathrm{C} \mathrm{NMR}\left(75 \mathrm{MHz}, \mathrm{CDCl}_{3}\right) \delta \mathrm{ppm}$ (anti 
only): $173.5,158.3,134.1,129.8,129.3,113.7,112.7$, 91.7, 76.0, 53.4, 17.9.

2.6 6-Dimethylamino-3-ter-butyltrimethylsilyloxy-2methyl-2,3-dihydro-benzofuran-2-carboxylic acid methyl ester 11a (anti only)

Imidazole $(0.81 \mathrm{~g})$ was added to a solution of $\mathbf{6 a}$ $(2 \mathrm{~g}, 7.96 \mathrm{mmol})$ in DMF $(20 \mathrm{ml})$. After $15 \mathrm{~min}$. of stirring under nitrogen atmosphere, TBDMS-Cl $(1.79 \mathrm{~g}, 8 \mathrm{mmol})$ was added. The solution was stirred overnight at room temperature and then diluted with water $(20 \mathrm{ml})$. The resulting mixture was extracted with $\mathrm{Et}_{2} \mathrm{O}(3 \times 50 \mathrm{ml})$ and the combined organic layers washed with water $(50 \mathrm{ml})$, dried over $\mathrm{MgSO}_{4}$ and concentrated. Purification (flash chromatography, silica, PE:EtOAc 97:3) gave 2.24 g of 11a as an oil (87\%). ${ }^{1} \mathrm{H}$ NMR (300 MHz, $\left.\mathrm{CDCl}_{3}\right) \delta$ ppm: $7.08(\mathrm{~d}, 1 \mathrm{H}, J=$ $8.1 \mathrm{~Hz}), 6.30(\mathrm{~m}, 2 \mathrm{H}), 6.1(\mathrm{~m}, 1 \mathrm{H}), 5.31(\mathrm{~s}, 1 \mathrm{H}), 3.72$ (s, 3H), 2.91 (s, 6H), $1.6(\mathrm{~s}, 3 \mathrm{H}), 0.91(\mathrm{~s}, 9 \mathrm{H}), 0.19$ (s, $3 \mathrm{H}), 0.17$ (s, $3 \mathrm{H}) ;{ }^{13} \mathrm{C}\left(75 \mathrm{MHz}, \mathrm{CDCl}_{3}\right) \delta \mathrm{ppm}: 174.2$, 160.5, 152.8, 125.8, 115.4, 105.9, 94.1, 91.5, 76.3, 52.7, $40.6,25.8,18.7,18.2,-44.1,-4.6$.

\subsection{6-Chloro-3-ter-butyltrimethylsilyloxy-2-methyl- 2,3-dihydro-benzofuran-2-carboxylic acid methyl- ester 11b}

Obtained as 11a as oil with a yield of $73 \%$. Anti isomer ${ }^{1} \mathrm{H}$ NMR $\left(300 \mathrm{MHz}, \mathrm{CDCl}_{3}\right) \delta$ ppm: $6.90(\mathrm{~d}, 1 \mathrm{H}, J=$ $8.0 \mathrm{~Hz}), 6.70(\mathrm{~m}, 2 \mathrm{H}), 5.15(\mathrm{~s}, 1 \mathrm{H}), 3.62(\mathrm{~s}, 3 \mathrm{H}), 1.6$ (s, 3H), $0.91(\mathrm{~s}, 9 \mathrm{H}), 0.19(\mathrm{~s}, 3 \mathrm{H}), 0.17(\mathrm{~s}, 3 \mathrm{H}) ;{ }^{13} \mathrm{C}$ $\left(75 \mathrm{MHz}, \mathrm{CDCl}_{3}\right) \delta$ ppm: 173.3, 159.6, 135.8, 126.7, $126.3,111.4,91.9,75.9,52.9,25.8,21.1,18.4,-4.0$, -4.4 .

Syn isomer ${ }^{1} \mathrm{H}$ NMR $\left(300 \mathrm{MHz}, \mathrm{CDCl}_{3}\right) \delta$ ppm: 6.94 $(\mathrm{d}, 1 \mathrm{H}, J=8.0 \mathrm{~Hz}), 6.70(\mathrm{~m}, 2 \mathrm{H}), 4.88(\mathrm{~s}, 1 \mathrm{H}), 3.65$ (s, 3H), 1.6 (s, 3H), 0.91 (s, 9H), 0.19 (s, 3H), 0.17 (s, $3 \mathrm{H}) ;{ }^{13} \mathrm{C} \mathrm{NMR}\left(75 \mathrm{MHz}, \mathrm{CDCl}_{3}\right) \delta \mathrm{ppm}: 170.1,157.8$, 136.0, 126.4, 126.0, 111.8, 92.8, 79.9, 52.3, 25.7, 22.2, $18.2,-4.1,-4.4$.

\subsection{5-Bromo-3-ter-butyltrimethylsilyloxy-2-methyl- \\ 2,3-dihydro-benzofuran-2-carboxylic acid methyl ester} 11c. Obtained as 11a as oil with a yield of $84 \%$

Anti isomer. ${ }^{1} \mathrm{H}$ NMR $\left(300 \mathrm{MHz} ; \mathrm{CDCl}_{3}\right) \delta$ ppm: 7.3 $(\mathrm{m}, 2 \mathrm{H}), 6.81(\mathrm{~d}, 1 \mathrm{H}, J=8.6 \mathrm{~Hz}), 5.37(\mathrm{~s}, 1 \mathrm{H}), 3.75(\mathrm{~s}$, $3 \mathrm{H}), 1.61(\mathrm{~s}, 3 \mathrm{H}), 0.91(\mathrm{~s}, 9 \mathrm{H}), 0.20(\mathrm{~s}, 6 \mathrm{H}) ;{ }^{13} \mathrm{C} \mathrm{NMR}$ $\left(75 \mathrm{MHz} ; \mathrm{CDCl}_{3}\right) \delta$ ppm: 173.1, 157.7, 133.1, 130.1,
$128.5,112.9,112.3,91.5,76.1,52.8,25.7,18.2,18.0$, $-4.2,-4.6$.

Syn isomer ${ }^{1} \mathrm{H}$ NMR $\left(300 \mathrm{MHz} ; \mathrm{CDCl}_{3}\right) \delta$ ppm: 7.3 $(\mathrm{m}, 2 \mathrm{H}), 6.81(\mathrm{~d}, 1 \mathrm{H}, J=8.59 \mathrm{~Hz}), 5.0(\mathrm{~s}, 1 \mathrm{H}), 3.76(\mathrm{~s}$, $3 \mathrm{H}), 1.59$ (s, 3H), 0.85 (s, 9H), 0.15 (s, 6H); ${ }^{13} \mathrm{C}$ NMR $\left(75 \mathrm{MHz}, \mathrm{CDCl}_{3}\right) \delta$ ppm: $169.9,158.0,133.2,129.5$, $128.5,112.7,112.6,92.2,80.0,52.3,25.5,22.1,17.9$, $-4.1,-4,6$.

\subsection{General procedure for hydrolysis of esters $\mathbf{1 1}$ to} acid 12. To a solution of ester $11(3 \mathrm{mmol})$ in $\mathrm{THF}$

$\mathrm{MeOH}(5: 1,12 \mathrm{ml})$ an aqueous solution of $\mathrm{LiOH}$ $(2.5 \mathrm{M}, 2 \mathrm{ml})$ was added. After stirring overnight at ambient temperature, the mixture was acidified to $\mathrm{pH}$ 1 with $\mathrm{HCl}(6 \mathrm{~N})$. The mixture was then diluted with $\mathrm{H}_{2} \mathrm{O}(50 \mathrm{ml})$ and saturated with $\mathrm{NaCl}$ and extracted with EtOAc $(6 \times 50 \mathrm{ml})$ until no more acid was found in the aqueous layer. The combined organic layers were dried $\left(\mathrm{MgSO}_{4}\right)$ and concentrated to give the crude acid. Minimum $\mathrm{CH}_{2} \mathrm{Cl}_{2}$ was then added to dissolve the acid, and $100 \mathrm{ml}$ of PE was added to obtain the acid as a white precipitate. After removal of the supernatant liquid, the acid was obtained as a white solid. This purification was repeated twice to have the acid pure enough for the next step, and in nearly quantitative yields.

2.10 6-Diméthylamino-3-ter-butyltrimethylsilyloxy-2methyl-2,3-dihydro-benzofuran-2-carboxylic acid pentolactone ester

To a solution of acid 12a (6 g, $25.5 \mathrm{mmol})$ in $\mathrm{CH}_{2} \mathrm{Cl}_{2}(65 \mathrm{ml}) \mathrm{EDC}(3.4 \mathrm{~g}),(R)$-pentolactone $(6.05 \mathrm{~g}$, $45 \mathrm{mmol}$ ) and DMAP (350 $\mathrm{mg})$ were added. The solution was stirred overnight, hydrolysed with water $(100 \mathrm{ml})$ and extracted with $\mathrm{CH}_{2} \mathrm{Cl}_{2}(2 \times 100 \mathrm{ml})$. The combined organic layers were dried over $\mathrm{MgSO}_{4}$ and concentrated. Purification (flash chromatography, silica, PE:EtOAc 30:70) gave $3.8 \mathrm{~g} \mathrm{(32 \% )}$ of the less polar isomer as an yellow solid and $3.3 \mathrm{~g}(28 \%)$ of the more polar isomer as an yellow solid.

Less polar isomer: ${ }^{1} \mathrm{H}$ NMR $\left(300 \mathrm{MHz}, \mathrm{CDCl}_{3}\right) \delta$ ppm: 7,08 (d, 1H, $J=8.1 \mathrm{~Hz}), 6.28(\mathrm{~m}, 2 \mathrm{H}), 5.37(\mathrm{~s}$, $1 \mathrm{H}), 5.31(\mathrm{~s}, 1 \mathrm{H}), 4.0(\mathrm{~m}, 2 \mathrm{H}), 2.93(\mathrm{~s}, 6 \mathrm{H}), 1.70(\mathrm{~s}$, $3 \mathrm{H}), 1.16(\mathrm{~s}, 3 \mathrm{H}), 1.01(\mathrm{~s}, 3 \mathrm{H}), 0.92(\mathrm{~s}, 9 \mathrm{H}), 0,17$ (s, $3 \mathrm{H}), 0.16(\mathrm{~s}, 3 \mathrm{H}) ;{ }^{13} \mathrm{C}$ NMR $\left(75 \mathrm{MHz}, \mathrm{CDCl}_{3}\right) \delta \mathrm{ppm}$ : $172.2,171.5,160.7,153.0,125.9,115.5,106.0,94.1$, $91.4,76.3,76.2,75.8,40.7,40.1,25.9,23.1,19.9,18.4$, $18.3,-4.1,-4.4$.

More polar isomer: ${ }^{1} \mathrm{H}$ NMR $\left(300 \mathrm{MHz}, \mathrm{CDCl}_{3}\right) \delta$ ppm: 7,0 (d, $1 \mathrm{H}, J=8.1 \mathrm{~Hz}), 6.28(\mathrm{~m}, 2 \mathrm{H}), 5.39(\mathrm{~s}$, 
1H), $5.30(\mathrm{~s}, 1 \mathrm{H}), 4.03(\mathrm{~d}, 1 \mathrm{H}, J=9.0 \mathrm{~Hz}), 3.99(\mathrm{~d}$, $1 \mathrm{H}, J=9.0 \mathrm{~Hz}), 2.90(\mathrm{~s}, 6 \mathrm{H}), 1.70(\mathrm{~s}, 3 \mathrm{H}), 1.12(\mathrm{~s}$, $3 \mathrm{H}), 1.03$ (s, 3H), 0.9 (s, 9H), 0.17 (s, 3H), 0.16(s, 3H); ${ }^{13} \mathrm{C}$ NMR (75 MHz, $\mathrm{CDCl}_{3}$ ) $\delta$ ppm: 172.6, 171.8, 160.9, 153.1, 126.1, 115.3, 106.2, 94.1, 91.3, 76.4, 76.2, 75.6, $40.7,40.3,25.9,23.0,19.9,18.5,18.3,-4.1,-4.4$.

2.11 6-Chloro-3-ter-butyltrimethylsilyloxy-2-méthyl2,3-dihydro-benzofuran-2-carboxylic acid pentolactone ester 13b. Prepared and isolated as 13a in $77 \%$ overall yield as a 1:1 ratio

Less polar isomer. ${ }^{1} \mathrm{H}$ NMR $\left(300 \mathrm{MHz}, \mathrm{CDCl}_{3}\right) \delta$ ppm: $7.2(\mathrm{~d}, 1 \mathrm{H}, J=8.7 \mathrm{~Hz}), 6.8(\mathrm{~m}, 2 \mathrm{H}), 5.43(\mathrm{~s}, 1 \mathrm{H})$, $5.30(\mathrm{~s}, 1 \mathrm{H}), 4.0(\mathrm{~d}, 1 \mathrm{H}, J=9.0 \mathrm{~Hz}), 4.0(\mathrm{~d}, 1 \mathrm{H}, J=$ $9.0 \mathrm{~Hz}), 1.70$ (s, $3 \mathrm{H}), 1.17$ (s, 3H), 0.93 (s, 3H), 0.90 (s, 9H), 0.20 (s, 3H), 0.19 (s, 3H).

More polar isomer: ${ }^{1} \mathrm{H}$ NMR $\left(300 \mathrm{MHz}, \mathrm{CDCl}_{3}\right) \delta$ ppm: $7.2(\mathrm{~d}, 1 \mathrm{H}, J=8.7 \mathrm{~Hz}), 6.9(\mathrm{~m}, 2 \mathrm{H}), 5.43(\mathrm{~s}$, $1 \mathrm{H}), 5.33(\mathrm{~s}, 1 \mathrm{H}), 4.05(\mathrm{~d}, 1 \mathrm{H}, J=9.0 \mathrm{~Hz}), 4.01(\mathrm{~d}$, $1 \mathrm{H}, J=9.0 \mathrm{~Hz}), 1.70(\mathrm{~s}, 3 \mathrm{H}), 1.14(\mathrm{~s}, 3 \mathrm{H}), 1.04(\mathrm{~s}$, $3 \mathrm{H}), 0.90$ (s, 9H), 0.20 (s, 3H), 0.19 (s, 3H); ${ }^{13} \mathrm{C}$ NMR $\left(75 \mathrm{MHz}, \mathrm{CDCl}_{3}\right) \delta \mathrm{ppm}: 171.6,171.6,159.9,135.9$, 126.6, 126.5, 121.8, 111.2, 91.6, 76.1, 75.8, 75.8, 53.5, $40.1,25.7,22.7,19.8,18.1,17.9,-4.2,-4.6$.
2.12 5-Bromo-3-ter-butyltrimethylsilyloxy-2-méthyl2,3-dihydro-benzofuran-2-carboxylic acid pentolactone ester 13c. Prepared and isolated as 13a in $80 \%$ overall yields as a 1:1 ratio

Less polar isomer. ${ }^{1} \mathrm{H}$ NMR $\left(300 \mathrm{MHz}, \mathrm{CDCl}_{3}\right) \delta$ ppm: $7.34(\mathrm{~m}, 2 \mathrm{H}), 6.78(\mathrm{~d}, 1 \mathrm{H}, J=8.9 \mathrm{~Hz}), 5.46(\mathrm{~s}, 1 \mathrm{H})$, $5.30(\mathrm{~s}, 1 \mathrm{H}), 4.00(\mathrm{~s}, 2 \mathrm{H}), 1.68(\mathrm{~s}, 3 \mathrm{H}), 1.16(\mathrm{~s}, 3 \mathrm{H})$, 0.94 (s, 3H), 0.92 (s, 9H), 0.20 (s, 3H), 0.18 (s, 3H); ${ }^{13} \mathrm{C}$ NMR $\left(75 \mathrm{MHz}, \mathrm{CDCl}_{3}\right) \delta \mathrm{ppm}: 171.4,158.0,133.1$, 130.3, 128.6, 113.0, 112.0, 91.3, 76.1, 76.0, 75.9, 39.9, 25.7, 22.9, 19.8, 18.1, 17.7, -4.2, -4.5.

More polar isomer: ${ }^{1} \mathrm{H}\left(300 \mathrm{MHz}, \mathrm{CDCl}_{3}\right) \delta \mathrm{ppm}$ : $7.4(\mathrm{~m}, 2 \mathrm{H}), 6.81(\mathrm{~d}, 1 \mathrm{H}, J=8.9 \mathrm{~Hz}), 5.44(\mathrm{~s}, 1 \mathrm{H})$, $5.33(\mathrm{~s}, 1 \mathrm{H}), 4.04(\mathrm{~d}, 1 \mathrm{H}, J=8.9 \mathrm{~Hz}), 3.95(\mathrm{~d}, 1 \mathrm{H}$, $J=8.9 \mathrm{~Hz}), 1.71(\mathrm{~s}, 3 \mathrm{H}), 1.14(\mathrm{~s}, 3 \mathrm{H}), 1.04(\mathrm{~s}, 3 \mathrm{H})$, $0.92(\mathrm{~s}, 9 \mathrm{H}), 0.20(\mathrm{~s}, 3 \mathrm{H}), 0.18(\mathrm{~s}, 3 \mathrm{H}) ;{ }^{13} \mathrm{C} \mathrm{NMR}$ $\left(75 \mathrm{MHz}, \mathrm{CDCl}_{3}\right) \delta$ ppm: 171.6, 171.5, 158.1, 133.3, $130.0,128.7,113.1,112.2,91.2,76.1,76.0,75.8,40.1$, $25.7,22.8,19.8,18.0,17.9,-4.2,-4.6$.

\section{Results and discussion}

Salicylaldehyde 7a is a known compound prepared by Vilsmeier-Haack formylation of 3-aminophenol 8a,

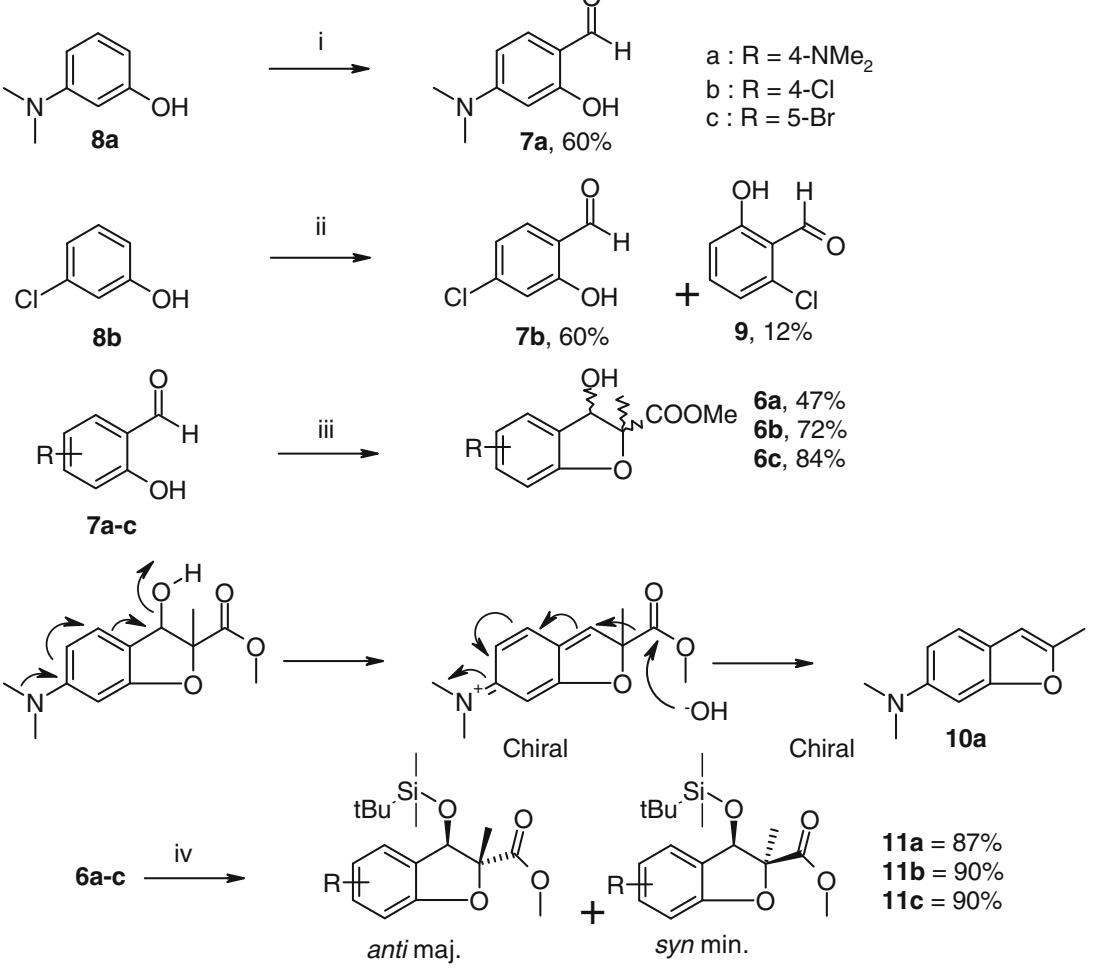

Scheme 1. i) $\mathrm{POCl}_{3} \mathrm{DMF}$ reflux; ii) $\left(\mathrm{CH}_{2} \mathrm{O}\right) \mathrm{n} \mathrm{MgCl}_{2}, \mathrm{NEt}_{3}, \mathrm{CH}_{3} \mathrm{CN}$; iii) $\mathrm{CH}_{3}-\mathrm{CHBr}-\mathrm{COOMe}, \mathrm{K}_{2} \mathrm{CO}_{3}, \mathrm{DMF}, 140^{\circ} \mathrm{C} 1 \mathrm{~h}$; iv) TBDMSCl, imidazole, DMF, chromatographic separation. 
Table 1. Determination of the anti-syn ratios of compounds 6 and $\mathbf{1 1}$ by ${ }^{1} \mathrm{H}$ NMR and $\mathrm{H}_{\text {benzylic }}$ chemical shifts.

\begin{tabular}{lcc}
\hline $\mathrm{R}$ & anti 6 ratio $\mathrm{H}_{\text {benzylic }}(\delta \mathrm{ppm})$ & syn 6 ratio $\mathrm{H}_{\text {benzylic }}(\delta \mathrm{ppm})$ \\
\hline $\mathrm{H}$ & 745.35 & 265.02 \\
$4-\mathrm{NMe}_{2}$ & 505.17 & Not detected \\
$4-\mathrm{Cl}$ & 79.65 .25 & 20.44 .90 \\
$4-\mathrm{Br}$ & 905.35 & 104.90 \\
& Anti $\mathbf{1 0}$ & Syn $\mathbf{1 0}$ \\
& $\mathrm{Ha}(\delta \mathrm{ppm})$ & $\mathrm{Ha}(\delta \mathrm{ppm})$ \\
$4-\mathrm{NMe} \mathrm{Me}_{2}$ & 5.31 & - \\
$4-\mathrm{Cl}$ & 5.15 & 4.88 \\
$4-\mathrm{Br}$ & 5.37 & 5.00 \\
\hline
\end{tabular}

while formylation of the chlorinated homologue $\mathbf{8 b}$ was obtained by Skattebol's method, using paraformaldehyde as the formyl source and $\mathrm{MgCl}_{2}$ as a catalyst ${ }^{14}$ (scheme 1). Interestingly, the Skattebol's method does not work with the aminophenol, while the VilsmeierHaack method was not convenient for $\mathbf{8 b}$. Aldehydes 7a-c were then reacted with 2-bromopropanoic acid methyl ester in the presence of $\mathrm{K}_{2} \mathrm{CO}_{3}$ in precisely controlled DMF reflux to directly afford the corresponding 2,3-dihydrobenzofuran-3-ol 6 as a mixture of diastereoisomers. The control of the reaction time and the temperature was critical, to avoid the formation of the corresponding benzofurans. In the particular case of compound $\mathbf{6 a}$, only the anti isomer was detected, with concomitant formation of the corresponding benzofuran 10a, whose formation could not be avoided. As only the anti isomer $\mathbf{6 a}$ was obtained with the benzofuran $10 a$, the formation of the latter from the syn isomer could not be determined. Unexpectedly, the brominated compound $\mathbf{6 c}$ was obtained with a very high diastereoselectivity, with an anti-syn ratio of 90:10, compared to the chlorinated counterpart with an anti-syn ratio of 79:21 (table 1), and the known unsubstituted analogue with a 74:26 ratio. For the brominated derivative $\mathbf{6 c}$, an easy separation of the anti and syn isomers could be achieved by precipitation, a result already observed for unsubstituted benzofuran-3-ols. ${ }^{12}$ This practical separation was not possible for compound $\mathbf{6 b}$. At this stage, prior to the replacement of the methyl ester by a chiral alcohol to achieve resolution, a protection of the 3hydroxyl group was found necessary. We also expected this protection to favour the general separation of esters $\mathbf{6}$ by the use of a bulk protecting group.

The mixtures of anti-syn alcohols $\mathbf{6 a - c}$ were thus protected as ter-butyldimethylsilyl ethers $\mathbf{1 1}$, and we observed an easy chromatographic separation of the isomers of derivatives $\mathbf{6 b}$, c. The anti-syn ratios for compounds 11 were determined by ${ }^{1} \mathrm{H}$ NMR analysis (table 1). The benzylic proton of the anti and syn diastereoisomers of compounds $\mathbf{1 1}$ appeared to be around 5.3 and $5.0 \mathrm{ppm}$ respectively. This $0.3 \mathrm{ppm}$ shift was attributed to the effect of the adjacent carboxyl

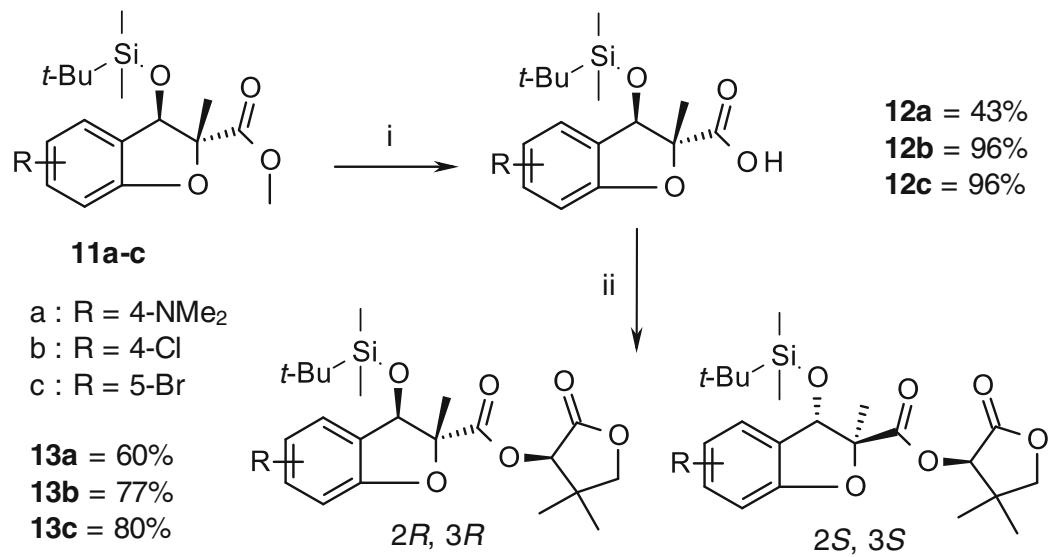

Scheme 2. (i) $\mathrm{LiOH} 2.5 \mathrm{M}, \mathrm{MeOH}$, THF; (ii) (R)-pentolactone, EDC, DMAP, $\mathrm{CH}_{2} \mathrm{Cl}_{2}$, chromatographic separation. 


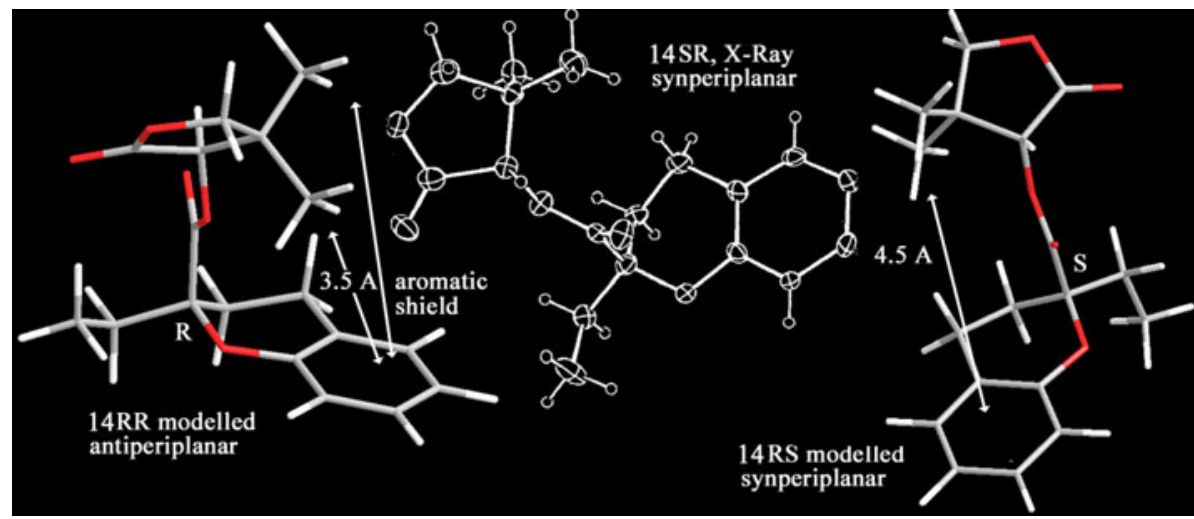

Figure 2. Modelled and X-Ray structure of pentolactone esters $\mathbf{1 3}$ and $\mathbf{1 4}$.

group in the anti isomers. Analysis of the diastereisomeric mixture 6 before the separation showed the same differences in anti and syn chemical shifts, confirming the initial ratio for compounds $\mathbf{6}$ and the fact that silylation did not modify the composition.

The resolution of the major anti isomers was then investigated with $(R)$-pentolactone. Hydrolysis of esters $\mathbf{1 1}$ afforded the corresponding acids $\mathbf{1 2}$ (scheme 2). Compound 11a once more gave the degradation product 10a, accounting for the moderate yield. These acids were esterified with $(R)$-pentolactone under EDC coupling conditions to afford esters 13a-c. In all cases, a 1:1 ratio of esters 13a-c was obtained and the two enantiomers were separated using chromatography. At this stage, X-ray analysis was unfortunately not possible, all isomers being obtained as deliquescent solids.
In order to determine the possible absolute stereochemistry of the isolated isomers, we compared our ${ }^{1} \mathrm{H}$ NMR results with literature data. Koyoma et al. prepared the diastereoisomeric $\boldsymbol{R}$ - and $\boldsymbol{S}$ - $(R)$-pentolactone esters 14 of a chroman derivative (figure 2). ${ }^{15}$ In the following text the second letter in $14 R R$ and $14 S R$ referred to the pentolactone chirality. In the case of the $14 R \boldsymbol{R}$ isomer a transesterification with $(S)$-pentolactone gave the $14 R S$ isomer suitable for $\mathrm{X}$-ray analysis, and allowing the determination of the absolute configurations. ${ }^{1} \mathrm{H}$ NMR chemical shift analysis showed significant differences for the methyl groups of the lactone moiety. One methyl group was shielded in the $14 R \boldsymbol{R}$ isomer (1.03 and $0.87 \mathrm{ppm}$, table 2, entry 1$)$, compared to the $\mathbf{1 4 S R}$ isomer (1.2 and $1.03 \mathrm{ppm}$, table 2, entry 2 ). The negative values indicated a shielding effect that must be due to the neighbour aromatic ring. The $14 R \boldsymbol{R}$

Table 2. $\quad{ }^{1} \mathrm{H}$ NMR comparison for reference compounds 14.

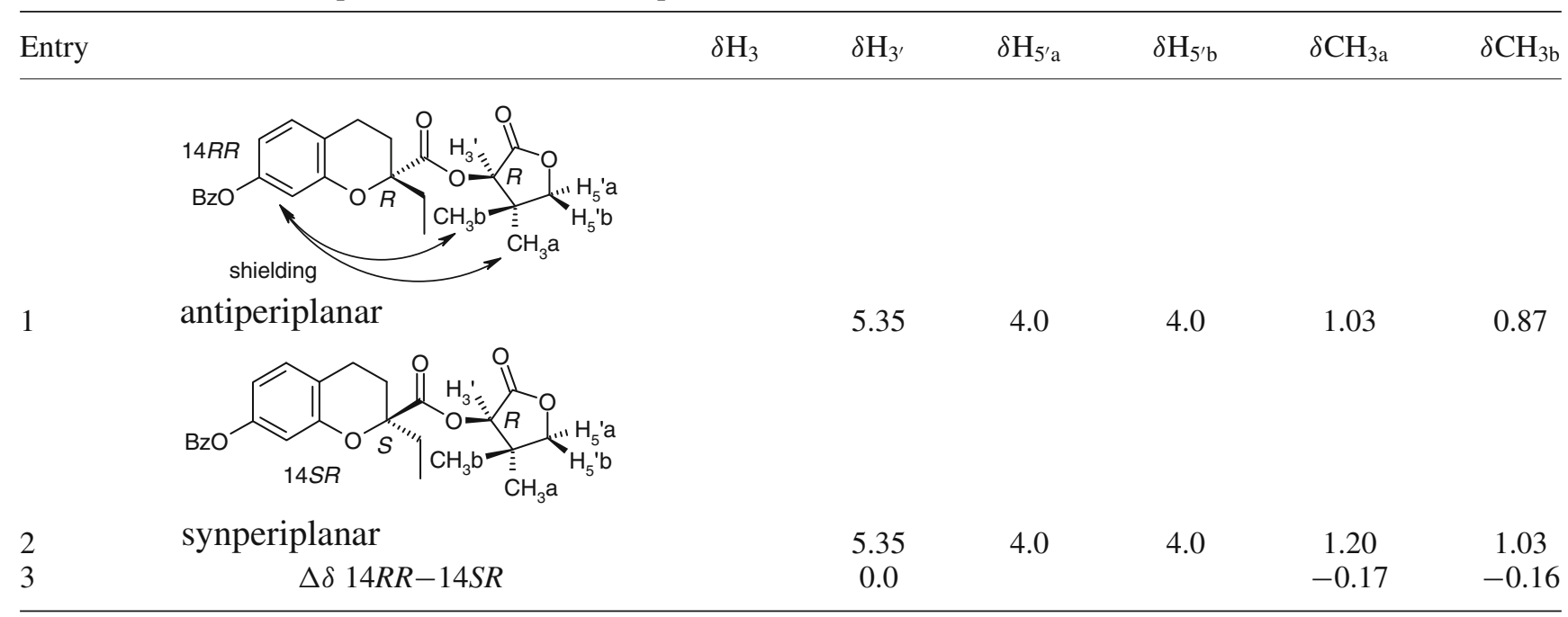


isomer corresponded to an antiperiplanar angle (130$140^{\circ}$ ) while the $\mathbf{1 4 S R}$ isomer gave a synperiplanar angle around the $\mathrm{O}=\mathrm{C}-\mathrm{C}-\mathrm{O}$ bonds $\left(15-30^{\circ}\right)$. Modelled isomers 14 gave stable anti- and synperiplanar conformers. The stable modelled $\mathbf{1 4 R S}$ conformer (figure 2) was found identical to the crystallographic structure obtained for the $\mathbf{1 4 S R}$ antipode. In this conformer, the lactone ring is $4.5 \AA$ away from the aromatic ring and the shielding effect is probably low. A stable $14 R R$ isomer was found with an antiperiplanar angle giving a $3.5 \AA$ distance between one lactone methyl group and the phenyl ring. The observed ${ }^{1} \mathrm{H}$ NMR chemical shifts are in agreement with a synperiplanar $14 S R$ conformer (identical to the X-Ray structure) and an antiperiplanar $14 \boldsymbol{R}$ conformer. The chemical shifts found for compounds 14 confirmed that the shielding effect must be distance-dependant.

The differences in chemical shifts for selected hydrogen atoms in compounds $13 S R$ and $13 R R$ were then calculated (table 3) and compared to $14 S R$ and $14 R R$ (table 2). For the halogenated compounds $\mathbf{1 3 b} \mathbf{b}, \mathbf{c}$, only one lactone methyl group $\left(\mathrm{CH}_{3 \mathrm{~b}}\right)$ appeared to be significantly shielded $(0.1 \mathrm{ppm})$. The lower values observed for compounds 13 compared to compounds 14 may be due to the five-membered rings that did not have real equatorial and axial positions, as can be found in

Table 3. $\quad{ }^{1} \mathrm{H}$ NMR comparison for compounds 13.

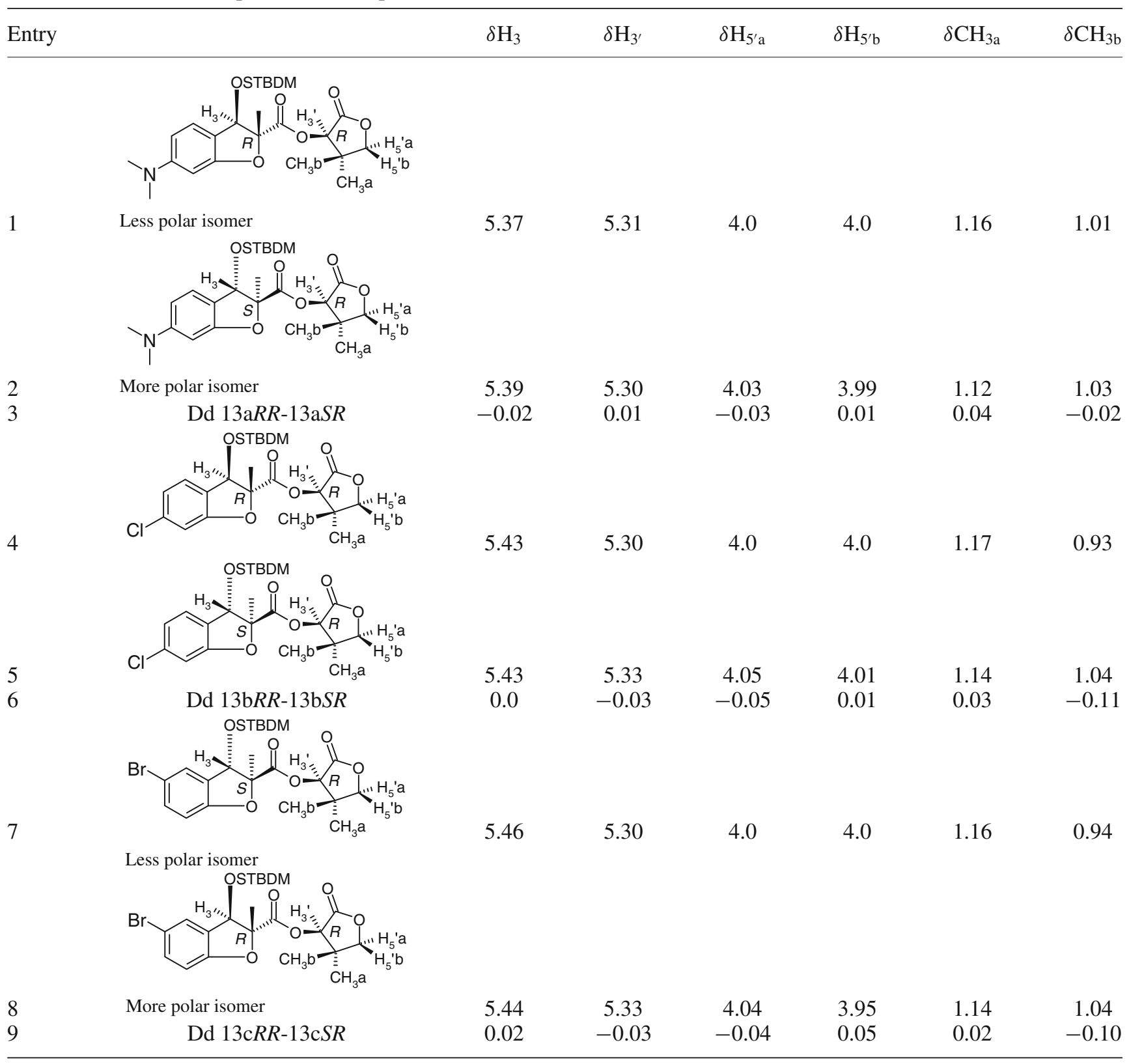


six-membered rings. Although we were not able to obtain X-ray data to confirm our proposal, we suggested the absolute configuration for compounds $\mathbf{1 3}$ as depicted in table 3 , in accordance with the results observed for compounds 14, and the fact that this shielding effect can probably be used in other circumstances.

\section{Conclusion}

A synthesis of 2,2-disubstituted-dihydro 2,2-disubstituted benzofuran-3-ols was investigated as an intermediate access to a wide range of structures. We showed that the initial introduction of a dialkylamino group was not convenient, giving an easier dehydration to the furan 10. Replacement by halogen atoms opened the way for potential modifications, with particular high anti diastereoselectivity for the bromide derivative. Derivatisation as ter-butyldimethylsilyl ethers provided a convenient and apparently general way to separate the syn and anti diastereoisomers 11 by chromatography. Their relative stereochemistry can be determined by ${ }^{1} \mathrm{H}$ NMR analysis and the enantiodifferentiation of the anti isomers has been achieved by transesterification with a resolving agent: $(R)$ pentolactone. Due to the impossibility of obtaining the syn isomers 6a or the lower syn isomers yields for $\mathbf{6 b}, \mathbf{c}$, this resolution protocol was not validated for the syn isomer. A method was proposed for the determination of the absolute configuration of esters $\mathbf{1 3}$ and was found efficient with the halogenated compounds. Work is currently in progress towards accessing enantiopure compounds $\mathbf{5}$ and assessing the importance of the stereogenic centre for the inhibitory activities of these compounds.

\section{Acknowledgements}

We thank Ministère de l'Education Nationale et de la Recherche (MENR), Centre National de la Recherche
Scientifique (CNRS) and La Ligue Contre le Cancer, Comité de Charente-Maritime for their financial support.

\section{References}

1. M R, Dobler, Bruce I, Cederbaum F, Cooke N G, Diorazio L J, Hall R G and Irving E 2001 Tetrahedron Lett. 8281

2. Shi G Q, Dropinski J F, Zhang Y, Santini C, Sahoo S P, Berger J P, MacNaul K L, Zhou G, Agrawal A, Alvaro A, Cai T-Q, Hernandez M, Wright S D, Moller D E, Heck J V, Meinke P T, 2005 J. Med. Chem. 5589

3. Mioskowski C, Gouverneur V, Couture K, Lesimple P, Autret J M 2000 PCT Int. Appl.; WO 2000015624 A1 20000323 CAN 132:222438 AN 2000:191073

4. Fukatsu K, Fujii N, Ohkawa S 1999 Tetrahedron Asymmetry 1521

5. a) Nemoto T, Ohshima T, Shibasaki M 2003 Tetrahedron 6889. b) Nemoto T, Ohshima T, Shibasaki M 2000 Tetrahedron Lett. 9569

6. Trend R M, Ramtohul Y K, Ferreira E M, Stoltz B M 2003 Angew. Chem. Int. Ed. 2892

7. Hodgson D M, Petroliagi M 2001 Tetrahedron Asymmetry 877

8. Charrier C, Clarhaut J, Gesson J-P, Estiu G, Wiest O, Roche J, Bertrand P 2009 J. Med. Chem. 523112

9. Asymmetric Synthesis, Part B, J D Morrison (ed) 1984, vol 3, 1, AP, New York

10. Derrick L, Clive J, Yu M, Sannigrahi M 2004 J. Org. Chem. 4116

11. Enders D, Hundermark T, Lazny R 1998 Synlett. 721

12. Pontillo J, Wu D, Ching B, Hudson S, Genicot M J, Gao Y, Ewing T, Fleck B A, Gogas K Aparicio A, Wang H, Wen J, Wade W S 2008 Bioorg. Med. Chem. Lett. 18 6151

13. Mioskowski C, Gouverneur V, Couture K, Lesimple P, Autret J-M 2000 WO Patent 15624

14. Hofslokken N, Skattebol L 1999 Acta. Chemica. Scandinavica 258

15. Koyoma H, Miller D, J, Boueres J K, Desai R C, Jones B, Berger J P, MacNaul K L, Kelly L J, Doebber T W, Wu M S, Zhou G, Wang P-R, Ippolito M C, Chao Y-S, Agrawal A K, Franklin R, Heck J V, Wright S D, Moller D E, Sahoo S P 2004 J. Med. Chem. 3255 